\title{
Methodological aspects of rural economy diversification in the context of modern civilizational transformations
}

\author{
Svetlana Podgorskaya ${ }^{1 *}$ \\ ${ }^{1}$ Federal State Budget Scientific Institution «Federal Rostov Agrarian Scientific Center» (FRASC), \\ Rassvet, st. Institutskaya, 1, 346735, Rostov region, Russia
}

\begin{abstract}
The purpose of the study is to provide theoretical and methodological justification for the directions of rural economy diversification in the context of modern civilizational transformations and new trends in economic development. Civilizational transformations are based on qualitative transformations affecting all levels of the world economic system, accompanied by a change in the technological structure, social and political organization. The new model of rural development should be based on a diversified economic base based on the principles of inclusive growth. In this regard, the state policy should be aimed at ensuring equal access of all segments of the rural population to production and financial resources, services, technologies and markets, and support for entrepreneurial initiatives, small and medium-sized businesses in rural areas. The priorities for the diversification of the rural economy in the context of modern civilizational transformations are to overcome single-industry specialization, to move to the versatile development of the economic basis of rural areas, to mobilize the local population and involve it in the economy on the basis of preserving and improving endogenous resources. The diversification of the rural economy is a global trend and is primarily driven by the desire to increase employment and sources of income of the rural population, and to overcome rural poverty.
\end{abstract}

\section{Introduction}

Currently, the paradigm of socio-economic development of the new civilization is being formed. This process takes place under the influence of global civilizational transformations. The main features of the new civilization are the globalization of all spheres of social activity, the formation of a new economic structure based on scientific, technical and information revolutions, the change of development targets to preserve the natural balance, overcome the problem of poverty, and a new quality of economic growth $[1,2]$.

The transformative civilizational potential is the phenomenon of the inclusiveness of the modern economy, a qualitative leap in the development of productive forces based on information and computer technologies has brought the modern economy to the possibility of a new revolutionary breakthrough - to the revival of an individually organized stage of so-

\footnotetext{
*Corresponding author: svetlana.podgorskaya@gmail.com
} 
cial production, which allows taking into account the personal characteristics of each of its participants [3].

The Strategy of the European Union until 2020 defines inclusive growth as "promoting the formation of an economy with a high level of employment, ensuring economic, social and territorial unity" [4]. The 2030 Agenda defines as a sustainable development goal the possibility of employment for everyone with decent working conditions and wages that can provide an acceptable standard of living.

Research and justification of scientific paradigms in relation to rural areas were carried out by such foreign and domestic scientists as: Frank E., Stephen B., Byerlee D., Janvry A., Sadoulet E., Ambrosio-Albalá M., Bastiaensen J. [5], Guinjoan E., Badia A., Tulla A.F. [6], Kostyaev A. [7] and others [8].

The most important role in the new model of rural development belongs to the diversification of the rural economy as a real possible mechanism for increasing income, reducing rural poverty, unemployment and increasing productive employment of the rural population $[9,10]$. The direct and synergistic effects of a diversified rural economy are: the preservation of the integrity of rural territories as a complex socio-economic system, with its specific features of development; improving the standard of living of the rural population through the development of high-quality social infrastructure and social security systems; developing the business sector of the economy and the system of cooperation; creating effective work of local self-government bodies; public organizations and civil society in general [11].

The above allows us to define the diversification of the rural economy in the context of modern civilizational transformations as a process of transformation not only of the productive forces (the emergence and spread of new types of economic activities) and the corresponding production relations, but also the reassessment of the role of man in various areas of life, turning him from a resource for ensuring economic growth into.

In this regard, the issues of studying the directions of diversification of the rural economy remain relevant, and such trends as the digitalization of agriculture, the development of technologies for the production of organic agricultural products, and new opportunities for non-agricultural employment in rural areas give a new impetus to these processes.

Despite the existence of a fairly wide range of studies on the issues of differentiated development of the rural economy in its various aspects, modern civilizational transformations determine new opportunities and directions of this process, which require their study and understanding.

\section{Materials and methods}

Official data of state statistics and reports of the Ministry of Agriculture of the Russian Federation, publications of domestic and foreign scientists were used as research materials. In the process of research, general scientific methods were used: analysis and synthesis; induction, deduction and analysis; abstraction; generalization; statistical and economic analysis.

\section{Results}

The concept of diversification in the economic sense first appeared in 1952 in an article by G. Markowitz on the optimization of the investment portfolio, for his portfolio theory, he was awarded the Nobel Prize in 1990. In the future, this theoretical direction was developed at the level of the enterprise, the firm as a way to expand the business by penetrating into other industries. The tasks of diversification were considered, first of all, as increasing the competitiveness of an economic entity, reducing risks due to a flexible response to market 
conditions, and obtaining additional profits through investments in profitable areas of production.

A great contribution to the development of the theory of enterprise diversification was made by Igor Ansoff, who considered it as a strategic reallocation of the company's resources to other areas of activity that are significantly different from the main ones, paying special attention to the strategy of developing new directions based on new skills and working methods.

Similar to corporate-level diversification, meso - and macro-level diversification is seen as a way to adapt to the changing needs and competitive conditions of regional, national and global economies by increasing the economic efficiency of using and combining development potential. If earlier the processes of diversification were mainly influenced by economic factors, such as economies of scale, risk reduction, the development of scientific and technological progress, technical and technological modernization, today, in the context of significant politicization of all spheres of life, the strategic directions and goals of diversification are largely determined by the geopolitical situation.

In the context of sanctions pressure and artificial barriers to the Russian economy, the issues of security and independence of the national economic complex of the country have become particularly relevant on the agenda. In this regard, diversification is considered as an instrument of import substitution policy, an export-oriented production model, and a means of increasing the sustainability of development [12].

The main difference between the diversification of the economy of the region (municipality) of diversification is that structural transformations affect the entire population of businesses operating in the territory, changes the structure of employment and output, and, consequently, requires state regulation of socio-economic, institutional and financial relations connected with it.

The diversification of the rural economy is closely associated with the concept of diversification of the regional economic structure and is primarily considered as a tool for increasing competitiveness. Since rural settlements occupy a significant share in the regional administrative and territorial structure of agricultural areas, the diversification of the rural economy should be part of a regional and macro-regional diversification strategy in order to obtain a synergistic effect from combining various elements of the development potential of the region and rural areas.

At the same time, the diversified development of the rural economy has its own characteristics, due to the specific characteristics of rural territories and a number of socioeconomic problems: high unemployment, low incomes of rural residents, low territorial and professional mobility of the labor force and its professional qualifications, insufficiently developed industrial and social infrastructure, etc.

With the spread of the theory of inclusive sustainable development, in addition to economic, the most important goals of diversification are to increase the level and quality of life of the population, to increase the rational use and protection of natural resources.

A review of scientific sources has shown that the most popular issues in the works of domestic scientists are the transformation of the economic structure of the agro-industrial complex, agricultural production, import substitution of agri-food products, which is reflected in the scientific works of N. Avarsky, A. Altukhov, R. Akhmetova, L. Bondarenko, M. Veselovsky, S. Govorov, E. Krylatykh, O. Rodionova, I. Sandu, V. Svobodin, I. Ushachev, S. Fisak, A. Chepik, S. Shanin, M. Shereuzheva, A. Yugaya and others.

A study of the scientific literature has revealed that there is currently no single approach to the interpretation of the concepts of "diversification of the rural economy" and "diversification of rural territories", there is a convergence of these categories and they are often used as synonyms. This situation is due to the fact that both definitions are based on the development of a territorial economic subsystem - socio-economic relations in rural areas as an 
administrative-territorial entity, and the scientific definition "rural territories" is used not just terminologically as a spatial characteristic, but also in a broader meaningful sense as a specific socio-ecological-economic system.

The problems of rural economy diversification in terms of preserving the natural resource potential of territories and its rational use, modernization and renewal of rural production and social infrastructure, development of cooperation, rural tourism, and others are considered in the studies of N. I. Antonova, I. N. Merenkova, S. L. Zakupnev, S. V. Kiselev, V. A. Kundius, V. D. Menshikov, A. A. Polidi, L. I. Rudenko, T. I. Sorokina, V. I. Trofimova, A. I. Firsov, N. S. Shakirov, and others.

Professor S. V. Kiselev defines the diversification of the rural economy as the most important factor of its sustainability due to direct action, when the diversity of the economic structure of rural areas allows to mitigate the negative effects on some industries by compensating for the development of other industries [13].

Diversification is the main tool for eliminating imbalances in the reproduction and redistribution of resources in rural areas, and it should be developed on the basis of the most complete and effective use of the territory's potential: natural, economic, human, and infrastructural $[14,15]$.

The opportunities for rural economy diversification are determined by the multifunctionality of agriculture, rural economy, and rural territories [13, 16]. Multidisciplinary farming involves the development of new types of activities, the more rational use of available resources, so that diversified rural areas as a whole are more stable and competitive in comparison with others.

It is customary to consider diversification at different levels of the economic system, its sectoral structure, relative to functional and process characteristics. The study of theoretical and methodological approaches to the development of diversification and rural areas allowed us to determine the following classification of diversification in relation to the rural economy (Table 1).

Table 1. Classification of types of rural economy diversification.

\begin{tabular}{|c|c|c|}
\hline $\begin{array}{l}\text { Classification } \\
\text { Feature }\end{array}$ & Types of diversification & Content \\
\hline 1 & 2 & 3 \\
\hline \multirow{3}{*}{$\begin{array}{l}\text { Hierarchical level } \\
\text { of the economic } \\
\text { system }\end{array}$} & $\begin{array}{l}\text { The macro-level (coun- } \\
\text { try) }\end{array}$ & $\begin{array}{l}\text { Development of rural areas in order to ensure the } \\
\text { economic security and competitiveness of the } \\
\text { country in the global economic structure }\end{array}$ \\
\hline & Meso-level (region) & $\begin{array}{l}\text { Balanced development of rural areas in the struc- } \\
\text { ture of the regional economy }\end{array}$ \\
\hline & $\begin{array}{l}\text { Micro-level (pre- } \\
\text { acceptance) }\end{array}$ & $\begin{array}{l}\text { Improving the market stability and competitive- } \\
\text { ness of economic entities in rural settlements }\end{array}$ \\
\hline \multirow{3}{*}{$\begin{array}{l}\text { Types } \\
\text { of activities }\end{array}$} & Agricultural products & $\begin{array}{l}\text { Crop production } \\
\text { Animal husbandry } \\
\text { Fish Farming } \\
\text { Forestry }\end{array}$ \\
\hline & Non-agricultural & $\begin{array}{c}\text { Industry } \\
\text { Construction } \\
\text { Handicraft production }\end{array}$ \\
\hline & Service sector & $\begin{array}{c}\text { Education } \\
\text { Health care } \\
\text { Consumer services } \\
\text { Retail trade } \\
\text { Public catering } \\
\text { Recreation area }\end{array}$ \\
\hline
\end{tabular}




\begin{tabular}{|c|c|c|}
\hline \multicolumn{3}{|c|}{ Continuation of table } \\
\hline 1 & 2 & 3 \\
\hline \multirow{2}{*}{$\begin{array}{l}\text { Regarding the } \\
\text { branch of the } \\
\text { economic com- } \\
\text { plex }\end{array}$} & Mono-industry & Within a single industry \\
\hline & Multi-industry & Within multiple industries \\
\hline \multirow{4}{*}{$\begin{array}{l}\text { Directions of } \\
\text { development of } \\
\text { production }\end{array}$} & Vertical & $\begin{array}{l}\text { Promotion along the technological chain of pro- } \\
\text { duction and sale of goods }\end{array}$ \\
\hline & Horizontal & $\begin{array}{l}\text { Creating a new product within the main profile, } \\
\text { expanding the sales channels of the product }\end{array}$ \\
\hline & Related & $\begin{array}{c}\text { The production of new products, the technical } \\
\text { characteristics are homogeneous with other prod- } \\
\text { ucts }\end{array}$ \\
\hline & Unrelated & $\begin{array}{c}\text { Production of new products that are not related to } \\
\text { traditional activities }\end{array}$ \\
\hline \multirow{2}{*}{$\begin{array}{l}\text { Using innova- } \\
\text { tion }\end{array}$} & Innovative & $\begin{array}{l}\text { Based on the application of world-class innova- } \\
\text { tions }\end{array}$ \\
\hline & Inertial & Based on the available competitive advantage \\
\hline \multirow{3}{*}{$\begin{array}{l}\text { Economic struc- } \\
\text { ture }\end{array}$} & $\begin{array}{l}\text { Large enterprises and } \\
\text { organizations }\end{array}$ & \multirow{3}{*}{$\begin{array}{l}\text { Differentiation of types and structure of production } \\
\text { of agricultural and non-agricultural products and } \\
\text { provision of services }\end{array}$} \\
\hline & $\begin{array}{l}\text { Small and medium- } \\
\text { sized businesses }\end{array}$ & \\
\hline & $\begin{array}{l}\text { Households of the } \\
\text { population }\end{array}$ & \\
\hline
\end{tabular}

Note: developed by the authors

The processes of diversification of the rural economy of Russia are combined with the trends in the development of the economy of agricultural areas in developed countries of Western Europe. In the agricultural areas of the European Union, the employment of the rural population in the main sectors of the rural economy is $14 \%$ in the primary sector, $28 \%$ in the secondary sector (industry) and 59\% in the tertiary sector (services) [17].

Based on the data [18] for the period 2005-2018 on the structure of employment of the rural population of Russia, it was found that $58.5 \%$ of rural residents are employed in the service sector, $19.6 \%$ in the secondary sector and $21.9 \%$ in the primary sector $\%$.

In the methodology of inclusive development, diversification of the rural economy we understand the expansion of economic activities and increase their contribution to socioeconomic development of rural areas on the basis of equal opportunity for all participants to improve rural livelihoods. In this regard, the diversified and inclusive development of rural areas, first of all, should promote the development of small and medium-sized businesses on the basis of equal access to material, financial, information resources, and innovative technologies; Digital technologies and networking are becoming an effective tool in solving these problems.

Among the main tasks of rural economic diversification, the primary one for ensuring economic growth is to increase the competitiveness of rural areas, primarily by making the most effective use of their potential. In this regard, it should ensure the development of the most promising, innovative elements of the economic system (industries based on intellectual resources and knowledge-intensive technologies) that can ensure sustainable economic growth and social development of the village in the long term [19, 20].

New trends of diversification are associated with the transition of the agri-food sector to a new technological structure, innovative technological transformations and relate to the new quality of final agricultural products, advanced technologies of crop production and animal husbandry: production of products with specified functional properties, production of organic products, biotechnology of crop production and animal husbandry, robotization 
of production processes, precision farming technologies, etc.

In 2019, the share of organizations that implemented innovations in agriculture was $16.3 \%$, in the seedling production sector $14.3 \%$. The growth rate of the indicator from 2016 to 2018 varied from 3.4 to $5.4 \%$, respectively, which is a good indicator for the industry. Despite the positive trends, in comparison with global competitors, Russian manufacturers look very modest, the gap in the level of innovation activity with some countries of the European Union reaches 4 times. Nevertheless, there are large advanced companies in the industry with a high proportion of qualified workers, using modern technologies and equipment, and actively introducing innovations. 36 large companies of the agro-industrial complex from the list of the top-50 in 2018 increased their investments in fixed assets by $8 \%$ (almost 86 billion rubles).) Compared to 2017 , this represents $17.6 \%$ of all fixed capital investments in the industry.

Large agricultural holdings are the main actors in the innovative transformation of the agricultural economy, as they have significant financial resources and opportunities to accumulate them for investing in advanced science-intensive technologies. According to FSSS, in 2018, the combined turnover of the country's 50 largest agricultural holdings accumulated two-thirds of the revenue of the entire Russian agro-industrial complex. On average, one enterprise accounts for 265 thousand hectares of farmland.

Diversification based on technological transformation of the agricultural sector will contribute to further differentiation of agricultural producers, primarily by strengthening the positions of large agricultural holdings. As a result, these stakeholders of technological transformation will gain even greater margin effect and strengthen their positions in the agri-food market.

Representatives of small and medium-sized agribusinesses mainly use traditional, less efficient technologies, which affects their competitiveness. Therefore, farmers are forced to move to niche markets and develop alternative types of employment.

For the purpose of sustainable development of rural areas, measures are needed to consolidate and develop the small and medium-sized business sector in rural areas. State support for this direction has confirmed its effectiveness - the production of agricultural products by peasant (farmer) farms has a positive trend, for 10 years the share of farmers has increased by $12 \%$. They have great prospects in the direction of organic agriculture, in particular organic animal husbandry. A significant barrier to entry into the industry for small forms can be the certification of farms, as a rather expensive procedure. Today, in the register of organic producers, only 13 are peasant (farm) farms or cooperatives.

Digitalization of agriculture is a necessary condition and a catalyst for innovative development in the agro-industrial complex. The importance of this direction is determined by the relevant departmental project, which at the state level determines the transition to a digital agricultural economy as a key driver of economic growth. The digital platform should ensure an increase in the efficiency of agricultural production by 2025 by increasing labor productivity in the industry by 2 times, reducing the cost of production by at least $20 \%$, and increasing the production of crop and livestock products by up to 1.5 times.

In the near future, the key directions in the development of digitalization of the agricultural sector are the formation of a single database of industry data; the introduction of a system for monitoring the traceability of agricultural products from the producer of agricultural raw materials to the consumer; simplification of procedures for obtaining state services in the agricultural sector.

The unified industry database of the agro-industrial complex will be put into commercial operation by the end of 2020. By 2021, the system should accumulate analytics on 20 thousand industry indicators, by 2024 - on 50 thousand, by 2030 - on 100 thousand indicators.

From 202113 pilot regions in test mode will work Information system of digital agri- 
culture, the system provides a comprehensive on-line service support - from the application, track its status, to obtain financing and the provision of reports on the use of budget funds.

It is expected that more than 100 thousand agricultural producers, as well as employees of regional agribusiness management bodies and local self-government bodies will become users of the service. It is planned that in $2024,75 \%$ of operations to provide state support to farmers will be carried out in digital format.

In addition, the platform has already collected 230 cases on various areas of agricultural production in the field of advanced innovative technologies.

One of the new promising areas of agricultural production is organic agriculture. Despite the fact that Russia is significantly inferior to developed countries in terms of production and consumption of organic products, it has the necessary potential to become a significant player in the world market. Experts note that this sector of the agricultural economy has been developing dynamically since 2016, the federal law "On the Production of Organic Products" came into force in 2020, and regional departmental programs are being actively developed.

The main trend of non-agricultural employment today is rural tourism [21, 22], the UN has declared 2020 the year of rural and eco-tourism. At the state level, the development of rural tourism is considered as an instrument for the development of rural areas. This direction became especially relevant in connection with the coronavirus pandemic, when most of the traditional tourist destinations abroad were closed for Russians.

The State Duma of the Russian Federation plans to adopt a law on rural tourism in the near future, which will create a legal framework and accelerate the development of rural tourism in Russia. The Ministry of Agriculture of the Russian Federation, in turn, has begun to develop measures for the development of rural tourism in the country. It is expected that in 2021, the ministry will begin to provide support to agricultural producers who will be engaged in rural tourism in the form of grants and concessional lending.

At the regional level, rural tourism provided legal support in the framework of the regional tourism development programs, or separately in the programs and concepts of rural tourism development. In 30 subjects of the Russian Federation, the concept of "rural tourism" or agricultural tourism is enshrined in regional laws, state programs, and concepts, 25 subjects provide state support at the regional level, and today 17 regional associations and resource centers for rural tourism operate.

In 2019, 586.4 thousand places for tourists were registered in rural areas (Fig. 1). Compared to 2014, the number of placements increased by 1.5 times. This reflects the growing need for such services in rural areas.

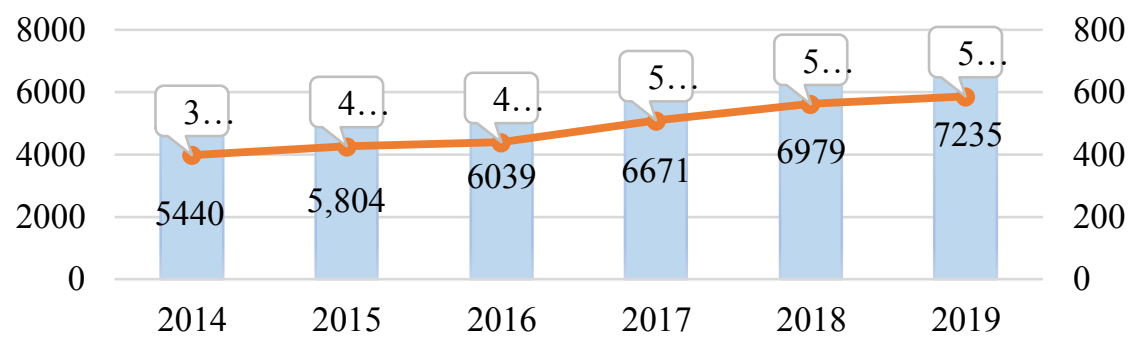

Number of collective placement facilities

- Number of seats in collective accommodation facilities, thousand

Fig. 1. Dynamics of collective accommodation facilities in rural areas. Note: compiled by the author based on the data [23]. 
The basic scheme of rural economy diversification in the new economic conditions based on the principles of inclusive rural development is presented in Fig. 2.

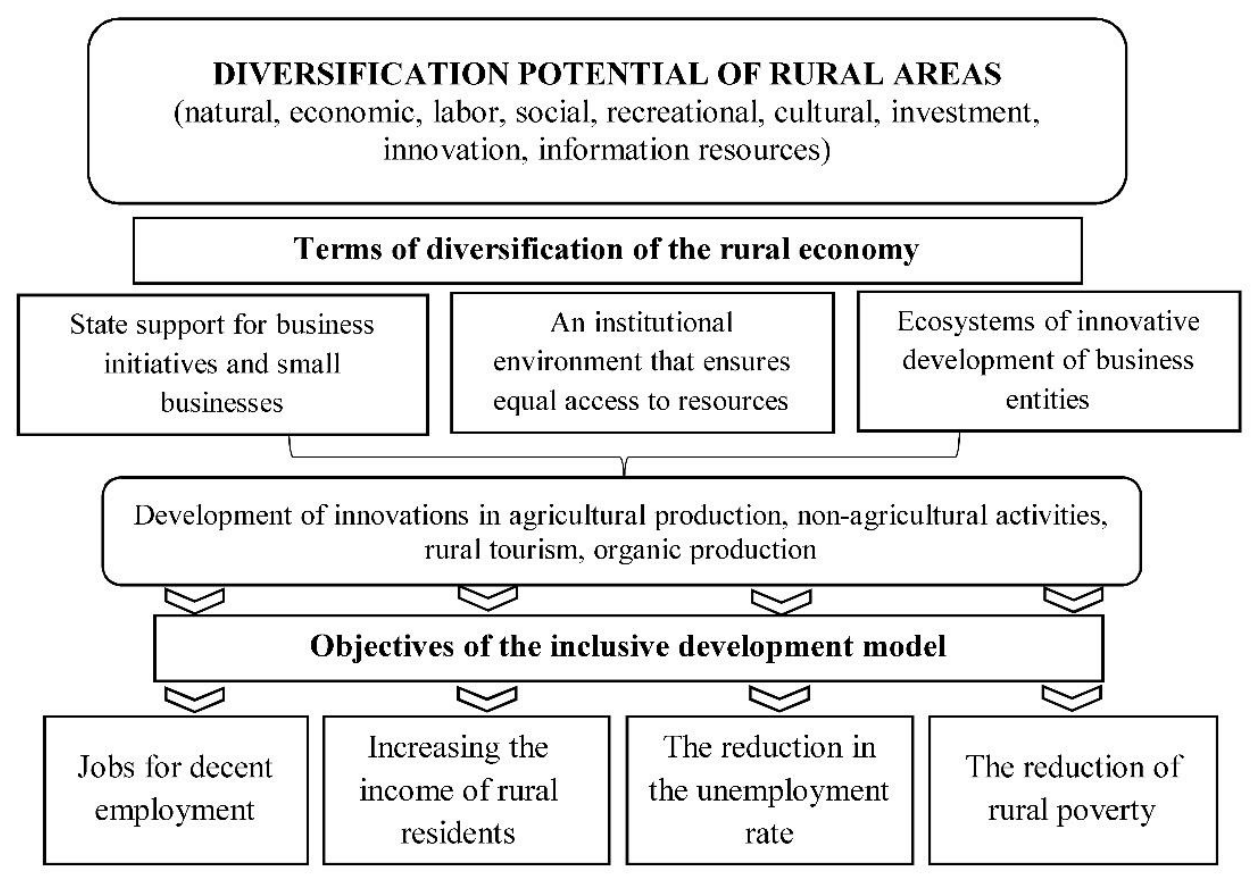

Fig. 2. Scheme of rural economy diversification in the new economic conditions based on the principles of inclusive development. Note: developed by the authors.

The diversification of the rural economy serves the goals of sustainable development of rural areas and is largely determined by the priorities of state policy. The goal of diversification in the new model of rural development is not economic growth, but the redistribution of income in the interests of all groups of the rural population through the transformation of the economic structure. First of all, we are talking about creating jobs with decent wages for the unprotected layers of rural residents.

\section{Conclusion}

Modern civilizational transformations are associated with the formation of an information, networked society, in which information and knowledge form the core of the competitiveness of national and regional economies, and information and communication technologies make it possible to implement integration processes of a social and economic nature almost instantly.

Such determinants of modern civilizational transformations as globalization, acceleration of scientific and technological progress, comprehensive informatization of social and economic activities, humanization of economic development goals, determine today the directions of rural economy diversification in the new model of rural development based on the principles of inclusive growth.

Rural areas of modern Russia are largely heterogeneous and differentiated by a number of indicators, such as the population, the level of technological development of agricultural production, the degree of development and availability of social infrastructure facilities and services, the state of engineering communications, distance from large agglomerations, etc. 
In this regard, strategies for the diversification of the rural economy should be developed taking into account the local territorial conditions and endogenous characteristics of the rural area, making the most complete and effective use of its potential.

The diversification of the rural economy should be determined by the state policy of inclusive rural development, aimed at broad promotion of the expansion of employment opportunities for the rural population and increasing the participation of the labor force in productive and income-generating activities.

\section{References}

1. D. J. Snower, International Organisations Research Journal, 14, 7-27 4 (2019), doi: 10.17323/1996-7845-2019-04-01.

2. L. Sullivan, L. Ryser, G. Halseth, Journal of Rural and Community Development, 9, 219-245 (2014)

3. S. Bodrunov, Society and Economy, 9, 5-21 (2016)

4. European Commission, Europe 2020. A European Strategy for Smart, Sustainable and Inclusive Growth (2010)

5. M. Ambrosio-Albalá, J. Bastiaensen, IOB Discussion Paper, 2 (2010)

6. E. Guinjoan, A. Badia, A.F. Tulla, Boletín de la Asociación de Geógrafos Españoles, 71, 495-500 (2016)

7. A. Kostyaev, Economics of Agriculture of Russia, 10, 88-103 (2018), doi: 10.32651/2070-0288-2018-10-88-103

8. OECD, New Rural Policy: Linking up for growth, in Proceedings of National Prosperity through Modern Rural Policy Conference, Memphis, USA (2015)

9. A. Rodríguez-Pose, Applied Geography, 61, 11-23 (2015)

10. M. Dirven, In Proceedings of IFAD Conference on New Directions for Smallholder Agriculture, 25 January 2011, Rome, pp. 24-25 (2011)

11. S. Podgorskaya, A. Podvesovsky, R. Isaev, N. Antonova, Business informatics, 3(13), 7-19 (2019), doi:10.17323/1998-0663.2019.3.7.19

12. I. Borisova, Management of Economic Systems: Scientific Electronic Journal, 4 (2015) URL: https://cyberleninka.ru/article/n/razvitie-mehanizma-diversifikatsii-ekonomikiregiona-arakterizuyuscheysya-preobladaniem-opredelennogo-vida-hozyaystvennoy

13. S. Kiselyov, Nikonovskie Readings, 13-15 (2019)

14. R. Adouki, A. Adukov, R. Yusufov, Bulletin of Oryol state agrarian University, 32, 38$42(2011)$

15. T. Sorokina, Journal of Economy and Entrepreneurship, 8-3 (85-3), 394-399 (2014)

16. S. Zakupnev, Competitiveness in the Global World: Economics, Science, Technology, 12 (59), 422-425 (2017)

17. Rural development in European Union. Statistical and economic information. Report (2013), URL: https://ec.europa.eu/agriculture/sites/agriculture/files/statistics/ ruraldevelopment/2013/full-text_en.pdf

18. On the state of rural territories in the Russian Federation in 2018. Annual report on the results of monitoring (Federal State Budgetary Scientific Institution "Rosinformagrotech", Moscow, 2020)

19. A. Kostyaev, Balt. Reg., 11, 93-113 4 (2019), doi: 10.5922/2078-8555-2019-4-6.

20. J. Esparcia, Journal of Rural Studies, 34, 1-14 (2014) 
21. P. Brouder, Tourism Planning and Development, 9, 333-337 (2012), doi: $10.1080 / 21568316.2012 .726259$

22. C. M. Hall, J. Hultman, S. Gossling, Sustainable Tourism in Rural Europe: Approaches to Development (Routledge, London, 2011)

23. O. Frolova, Bulletin NGIEI 2 (81), 111-122 (2018) 